\title{
明治初期における厚田場所の漁場施設と役宅の変遷に関する考察 北海道・厚田における漁場開発と集落発展に関する研究 その 2

\author{
OBSERVATION ON TRANSFORMATION OF FISHERY FACILITIES \\ AND HOUSING FOR OFFICIALS OF ATSUTA BASHO \\ IN EARLY MEIJI PERIOD
}

Studies on fishery exploitation and settlement development in Atsuta, Hokkaido Part 2

外崎由香*, 松下瑛 美**, 三宅理一***

Yuka TONOZAKI, Akimi MATSUSHITA and Riichi MIYAKE

\begin{abstract}
Fishery management in Hokkaido (Ezochi) underwent radical transformation after the foundation of Kaitakushi (Hokkaido Development Bureau) in 1869. Atsuta Basho, which used to be one of the 85 fisheries in Ezochi (Hokkaido) in Edo Era, came to be under the direct control of Kaitakushi, which established its branch office in Oshorkot, making use of old Unjoya, trading house equipped with accommodation for fishermen. Construction of housing facilities for officials started in 1870. Examination of remaining documents enables the schematic reconstruction of Unjoya, which was renamed into Honjin (official inn) in late 1869, and several houses for officials as well as their transformation process. After the abolition of Kaitakushi branch office in 1875 , all these official buildings were to be demolished, reused as a temple or relocated to another town by government property disposal procedure. This research based on the analysis of old documents and drawings executed by Kaitakushi leads to the clarification of facility and housing planning in Oshorkot and Kotanbet, which started from an indigenous ainu settlement, at the early phase of Kaitakushi rule.
\end{abstract}

Keywords : Ezochi, Unjoya, housing for officials, disposal of government property, standardization, Basho 蝦夷地，運上家，役宅，払下げ，標準化，場所

\section{1. はじめに}

藩政期の北海道（蝦夷地）沿岸部は場所と呼ばれる漁場単位に分 割され、場所請負制によってその開発と経営がなされていた。場所 には運上家、蔵、番屋など一連の漁場施設を置き、中でも運上家は

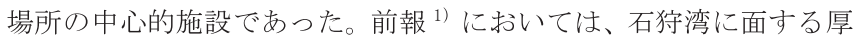

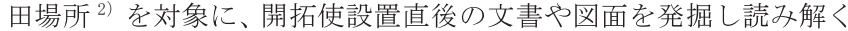
ことによって、江戸末期の厚田場所の土地利用を復元し、そこから 明治初年にかけての場所の変遷を解明した。具体的には、（1）アイ 又と和人の混住、(2) 厚田場所の土地利用区分、(3) 集落形成の特 質、（4）交易場の復元と消滅過程の 4 点が明らかとなった。

北海道建築の歴史を知る上で運上家 ${ }^{3)}$ 及び役宅 (官舎) ${ }^{4)}$ は重要 な建築物であるが、当時の状況を示寸図面史料は少なく、実際、厚 田場所の運上家に関する建築図面は残っていない。江戸末から明治 初期にかけての漁場施設や住居に関寸る研究は史料の散逸や研究者 不足のため未解明の部分が多い。唯一の先行研究として明治初期の 札幌の官舎研究を行った遠藤明久の『開拓使営繕事業の研究』 ${ }^{5)}$ が 貴重な知見を与えてくれる。遠藤は札幌の開拓使官舎建築を 3 期に 分け、第一は明治 5 年以前の和風官舎、第二は明治 6 年の洋風官舎 (前期洋風官舎)、第三は明治 11 年以降の洋風官舎（後期洋風官舎） と名付けて考察を行っている。明治 6 年以後の洋風建築については 遠藤の意思を受継いだ越野武の『北海道における初期洋風建築の研
究』6) などがある。明治 5 年以前の役宅（和風官舎）は、後述する ように、それまでの江戸時代の建築とは異なった新しい建築形式を まとい、開拓使設置に伴う新たな施設計画を示寸ものであるが、今 日まで研究が進んでいない。

本論文では、前報では扱わなかった江戸末から明治初期にかけて の建築的課題、具体的には厚田場所の運上家と役宅を対象に史料や 図面を考察し、建築形式の確立と変遷を辿ることを目的とする。

\section{2. 研究方法}

本論文は各地の史料館等に所蔵される史資料を用いた文献研究に 石狩市の公図（GIS 地図）を用いた土地利用研究を重祇、滅失した 建造物の編年と復元を行うことを基本とする。主史料としては前報 同様、北海道文書館所蔵の『厚田郡諸調』（以下『諸調』）と北海 道開拓記念館所蔵の『厚田全郡漁場圖面』 ${ }^{8)}$ （以下、『圖面』）に加 えて、『圖面』に類似した石狩市能量寺 ${ }^{9)}$ 所蔵の『古潭村街画正見 込調図』(以下『調図』) ${ }^{10)}$ 、開拓使と厚田出張所の諸連絡をまとめ た『厚田往復 明治四辛未年』(以下『厚田往復』) ${ }^{11}$ を用いる。さ らに役宅の編年では、『開拓使公文録 明治八年』(以下『開拓使公 文録』） ${ }^{12)}$ に綴じられた役宅平面図、『略輯旧開拓使会計書類』13) に綴じられた役宅平面図が建築形式の手がかりとなる。

\footnotetext{
* 藤女子大学人間生活学部 非常勤講師

** 北海道大学大学院工学研究院 博士課程

*** 藤女子大学大学院人間生活学研究科 教授
} 


\section{3. 史料の制作年の同定}

『諸調』は、厚田場所が明治 2 （1869）年に開拓使に移管されて から約 2 年間の厚田の様子を厚田詰の横山権少主典と梁瀬真精権少 主典らが記した書類を編纂したもので、文中に役宅平面図 1 件が描 かれているほか、役宅平面図 2 葉（横山邸、築瀬邸）が添付されて いる。『圖面』には制作年の記入がないが、前報の考察の結果、制作 年が明治 4 年（1871）末から翌年にかけてと絞られ、さらなる検証 を本論文で行う。他方、『調図』は、『圖面』と同様に漁場の人別、 地籍、建造物等が記され構図もほぼ同じである。制作者、制作年が 記されておらず、描かれた内容から、おおよその制作年を推定する。

また、諸史料を年代順に並べると、『厚田郡諸調』明治 2～4（1869 ～1871） 年、『浜益・厚田往復留 明治三年午七月』明治 3 （1870） 年、『厚田往復 明治四辛未年』明治 3～5（1870～1872） 年、『厚田 往復 明治六年壱月ヨリ十二月二至』明治 5～6（1872～1873） 年、 『開拓使公文録 明治八年』明治 7 9 (1874 1876) 年、『石狩来 書留 明治八年自一月至二月』明治 8 （1875）年、『石狩往書留 明 治八年自一月至二月』明治 8 (1875) 年、『略輯旧開拓使会計書類』 明治 9 (1876) 年である。これらの史料の考察により、厚田場所に おける明治 2～9（1869～1876） 年の変遷を辿ることが可能である。

なお、本論文で記された日付は、旧暦明治 5 年 12 月 3 日（新暦明 治 6 年 1 月 1 日）の改暦施行以前のものは旧暦であり、西暦との間 に 1 カ月弱のずれがある点を付記する。

\section{4. 交易場、役場、社寺地の施設計画}

『圖面』、調圖』とも厚田場所の基幹施設が集まる今日の古潭（コ タンベッ)・押琴 (ヨショロコッ) の施設配置を具体的に描いている (図 1、2)。場所に設置された施設群は次の通りである。

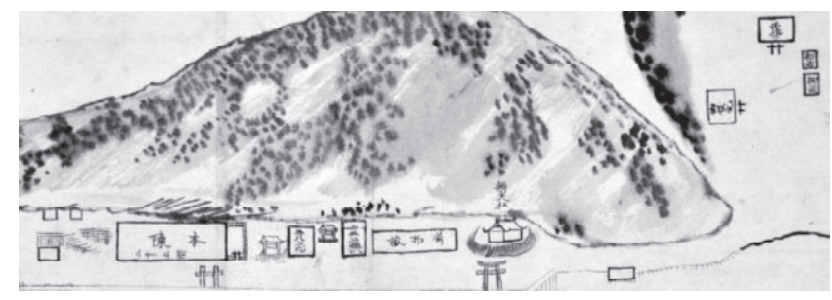

図 1 『厚田全郡漁場圖面』、手前が交易場、山側奥が出張所・役宅

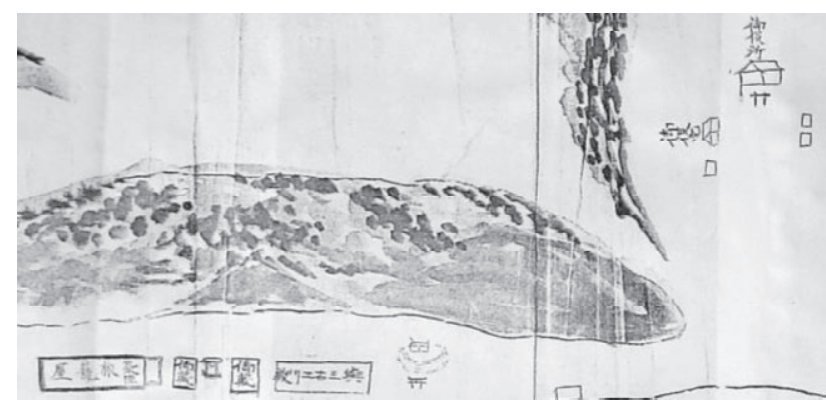

図 2 『古潭村街画正見込調圖』、手前が交易場、山側奥が御役所・役宅

\section{(1) 運上家}

請負人による漁場経営の拠点であり、和人とアイヌの交易場所、 出稼者の宿泊施設を兼㸚た場所最大の建造物であった。1つの場所 に 1 力所設置されており、建坪を眺めると、東蝦夷地では勇払場所 が最大の 252 坪で平均建坪は 163 坪、西蝦夷地ではルルモツが最大
の 283 坪で平均は 146 坪であった。 ヨショロコツの運上家について は、次項で詳述するが 192 坪でほぼ平均的な規模の施設であった ${ }^{14)}$ 。 (2) 藏

蔵には板藏、二八藏 ${ }^{15)}$ 、米藏などの収納藏があった。『圖面』、『調 図』の運上家脇にある 2 棟の蔵は『諸調』においても運上家脇に藏 が 2 棟（梁間 6 間桁行 7 間、梁間 6 間桁行 8 間）と記されている。 ( 3 ) 番屋

番屋は広い意味で使用され、場所内の便利なところに設けて番人 が管理したものや ${ }^{16)}$ 、漁夫の監督、漁場の見張り、漁期以外の番人 居所とされた ${ }^{17)}$ 。『諸調』にも番屋の記述がいくつか残されている。

(4) 役宅・出張所

北海道開拓使設置の明治 $2(1869)$ 年 7 月から 4 か月後の 11 月に 北海道開拓使厚田出張所が設置され、翌明治 3（1870）年 2 月に横 山権少主典 ${ }^{18)}$ と梁瀬権少主典 ${ }^{19)}$ らが赴任するのに合わせて役宅が 建てられた。役宅と出張所の詳細については第 6 章で後述する。

(5) 社寺

集落形成にあたり、大漁祈願、安全祈願など精神の安らぎを得る ために神社仏閣が建立された。厚田場所の記録の中で神社が現れる のは安政 5 (1776) 年の『蝦夷全地 西蝦夷地浜アツタ絵図』20)で、 「ヨショロコツ」の位置に「弁天」、「イナリ」の文字、朱色で鳥居 印が描かれている。『諸調』にはヨショロコツに辨天社（梁間 2 間、 桁行 2 間半) が 1 棟記されており、同様に『圖面』、『調図』にも ショロコツに辨天社が確認できる。

厚田場所で最も古く建てられた寺院は曹洞宗龍澤寺で、文久 1 (1861) 年 5 月、当時の場所請負人である平田興右衛門が建立した。 『圖面』には古潭川向こうに龍澤寺が記されており、『諸調』にも同 様に「龍澤寺一棟コタンヘッニ有境内四方三十五間」と記されてい る。だが明治 7 （1874）年に同寺は風雪のため大破、明治 8 （1875） 年に開拓使より役宅 1 棟が龍澤寺に払下げられ、移転する。

\section{5. 運上家の変遷}

\section{1. 運上家の成立と開拓使への移管}

厚田場所は宝永 3 (1706) 年に増毛場所より分割され、アツタ ${ }^{21)}$ の地に開設された。運上家の名称は安政 5（1776）年に初めて登場 し、史料によって運上屋もしくは運上市の表記の違いがあるが、開 設以降、北海道開拓使設置の明治 2（1869）年まで続く。

開拓使は場所経営の直営化を断行する。明治 2 年 9 月 28 日に場所 請負制廃止を布達、同 10 月 29 日、「請負名目被廃候二付、当分漁場 持卜相唱可申、其余ノ義八従前ノ通リ」とし、請負人から漁場持ち 一名称変更、官による漁場直別きの方針を打ち出し、運上家の本陣 への改称指令を出している ${ }^{22)}$ 。明治 5 年 1 月には本州で本陣が廃止 されたのにならい、本陣を旅籠屋並、同年 4 月にはさらに旅籠屋と 改称する布達がなされた。これまでは主に幕吏や藩吏、開拓使官吏 の利用であったが、一般人に開かれた。さらに同年 5 月に旅籠屋を 驛場、8月に驛聥扱所へと改称し、短期間での呼称変更を繰り返寸。

上記の制度改革の流れを背景にアツタ場所に関する記録に絞り込 んで考察を行うと、明治 $11 〜 18(1878 〜 1885)$ 年にまとめられた『厚 田郡戸長役場文移録』 ${ }^{23)} に 、$ 運上家が本陣と改称されたのが明治 2 年 12 月、次いで本陣から旅籠屋に改称されたのが明治 4 年 (月日不 明）で、翌明治 5 年 12 月には㶠莪へと改称したとある。開拓使の布 
達から地方で実際に改称されるまでに相当の時間差があった。

主史料の『諸調』には、運上家に関する記述が 3 カ所あり ${ }^{24)} 、 い$ ずれも上記の運上家が廃止され本陣と名称を改めた内容と合致する。 『厚田往復』でも、文中に本陣の名称が記載されているのは、明治 4 年 10 月までであり、改称されてから、この時期まで本陣と称して いたことが確認できた。驛莪に関しては、有力商人であった佐藤辨 藏の墓石背面に「明治六年一月一村を代表して驛派及び通行取扱 の委託」の文字が刻まれていることから、改暦の点を考慮すると、 先述した時期と合致する。

『圖面』と『調図』を考察寸ると、『圖面』には「本陳〔ママ〕二 十五間」(図 3）の文字、『調図』(図 4) では「旅籠屋（元本陣）」の 文字が確認できる。ともに制作年の記入はないが、図中の旧運上家 の名称から、『圖面』は明治 4（1871）年末から明治 5（1872）年初 めの建立ということになり、『調図』はその直後で明治 5（1872）年 内に描かれたものとみなしうる。

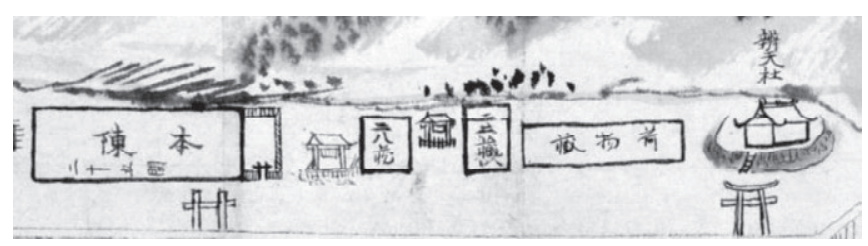

図 3 『厚田全郡漁場圖面』本陳〔ママ〕が運上家

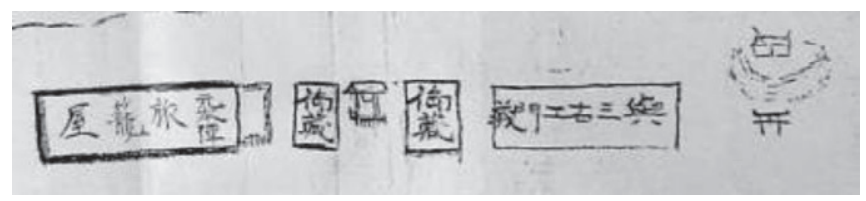

図 4 『古潭村街画正見込調図調図』の元本陣旅籠屋が運上家

\section{2. 運上家建築}

厚田場所の運上家を示す建築図面は現存せず、手がかりとなるの は1859（安政 6 年）『西蝦夷唐太道中記（竹）』(以下『道中記』） 25) の絵図（図 5 の左）と『圖面』(図 3) である。『道中記』から、切 妻平入りで玄関と入口が設けられていることがわかる。

唯一現存寸る下余市運上家 ${ }^{26)}$ ならびに図面が残る積丹運上家 ${ }^{27)}$ （図 6）を参照すると、同様に玄関と入口が設置され、ともに上手 が役人・請負人用、下手が漁民用に分けて使用されていた点が確認 できる。厚田場所の運上家は立関・入口の破風の大きさから図 5 の ように向かって左側が上手、右側が下手であり、下余市、積丹運上 家と左右は反転しているが同様の形式であったことが窺える。加え て、『圖面』から向って右手に柵が確認でき、柵内は魚を干寸作業を 行う場所であることから、右側が下手であったことが補完される。

上手内部の平面計画を考察すると、下余市運上家では、梁間 9 間 に対し、幅 1.5 間のとうり（廊下）を挟んで奥行 2.5 間と 3 間の座 敷群、その南に幅 1 間の縁が設置され、積丹運上家では梁間 9 間に 対し、幅 2 間のとうりを挟んで両側に奥行 2 間の座敷群、その外側 に 1.5 間の縁が囲む構造であることがわかる。『圖面』では厚田運上 家の梁間寸法が記されていないが、『諸調』には桁行が 25〜27 間 3 尺、梁間が $7 \sim 8$ 間と記されており（表 1 ）、下屋や雪隠等を外した 母屋部分で桁行 25 間、梁間 7 間であった可能性が高い。

この点を前提に、下余市運上家と積丹運上家を参考に、想定され
うる運上家基本スキームを図 6 に示す。上手はとうり（廊下）を挟 んで座敷群、その外側に縁が配されて式台付の玄関が取り付く。下 手は台所と土間を基本となし、入口が取り付く。幕末に蝦夷各地を 巡察した松浦武四郎も「ヨショロコツ運所家泊リ」と的としており、 この運上家に宿泊したことが推測できる。現在の GIS マップにはオ ショロコツにこの運上家ならびに蔵の規模に対応した地籍が残存し ており ${ }^{29)}$ 、運上家相当部分がふたつに分割されていることから、そ の境界が払下げにあたって上手・下手を分割したラインと読み込む ことも可能であるが、今後の考古学的な調査が必要である ${ }^{30)}$ 。

明治 22 (1889) 年に石油探索を目的として古潭一帯を描いた測量 地図 ${ }^{31)}$ には運上家の建物は描かれていない。その頃には行政の中 心が古潭から厚田に移り、旧運上家は必要性を失い、それまでに解 体されたと思われる。今日、この場所に礎石など一部見られるため、 今後の専門家による発掘に最終的な復元を委ねたい。

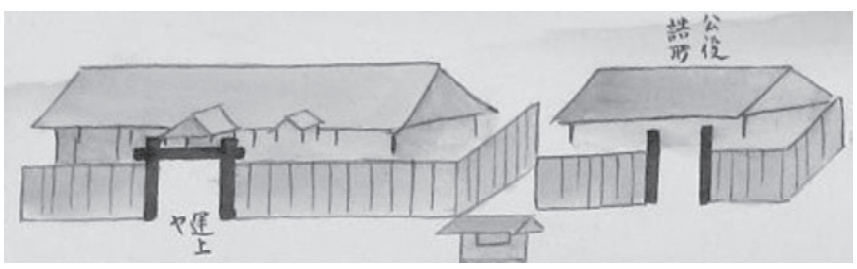

図 5 『西蝦夷唐太道中記 (竹)』アツタヨショロコツの図 左が運上家

表 1 『諸調』文中の運上家

\begin{tabular}{|l|l|l|l|}
\hline \multicolumn{1}{|c|}{ 簿 書 名 } & \multicolumn{1}{|c|}{ 桁 行 } & 梁間 & \multicolumn{1}{|c|}{ 備 考 } \\
\hline 厚田郡諸調書ノ件 & 27 間 3 尺 & 7 間 & 明治 2 年引継時 \\
\hline 厚田郡諸調書 & 27 間 3 尺 & 7 間 & 明治 2 年記入、明治 4 年編纂 \\
\hline 厚田御場所本陣藏々役邸建家調 & 25 間 & 8 間 & 明治 3 年 8 月 \\
\hline
\end{tabular}

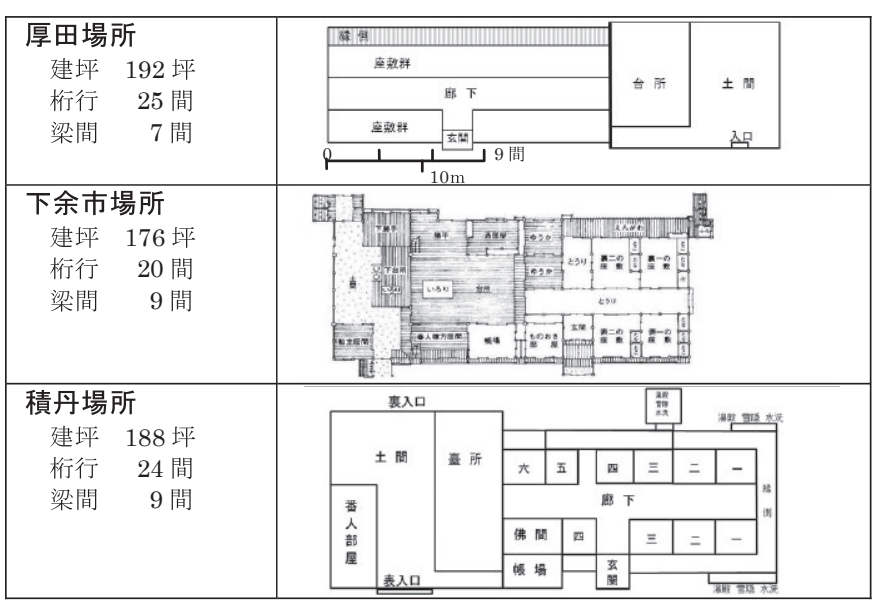

図 6 厚田運上家基本スキーム（上）、下余市運上家（中）積丹運上家（下）

\section{6. 役宅（役邸）の変遷}

開拓使設置に伴って明治 2（1869）年 11 月に厚田郡出張所が置か れ、翌明治 3 (1870) 年 2 月に横山権少主典と梁瀬権少主典らが赴 任する。その後、厚田出張所は石狩出張所に併合される明治 7 (1874) 年 1 月まで機能寸る。権少主典らの住居として建てられた役宅 2 棟 の図面が明治 3 年の文書に付帯して『諸調』に綴じられており、各々 の氏名が書き込まれている。4 間 8 間の役宅は横山権少主典と齋藤 綱良附属（後に使部）が同居し（図 7)、もう一方沖 4 間 4 間 3 尺で 縩瀬が住んでいた（図 8)。以下、図面や諸史料の考察を通して役宅 の建築形式を検証し、その変遷を辿る。 


\section{1. 龍澤寺へ払下られた役宅の考察（明治 7 年）}

明治 7 (1874) 年 1 月に厚田出張所は廃止され、隣の石狩出張所 に併合された。翌明治 8（1875）年 7 月、下記の記録にあるように 出張所付役宅（官邸）は龍澤寺に払下げられた。

『開拓使公文録』中の「厚田郡古潭村旧出張所付官邸払下方ノ件」 に「御拂下願書 一 金百五円二銭五厘 右者御当郡旧官宅壱棟御 拂下被成下度別紙代價積リ并圖面 $コ$ 以奉申上候右建家御地所共被仰 付度奉願上候此建家遣方之儀八当村竜澤寺為風雪大破二及居葬祭説 教等之節多人数居処モ無之候二付佛像并僧侶共移住為致度檀家一統 之志願二御座候間何卒如願被仰付被下置度此段奉難願候以上 古潭 願人佐藤辨藏 同平野忠右衛門 八年七月三日」とある ${ }^{32)}$ 。

払下げ時の平面図も収められており、「厚田郡古潭村御出張所建家 壱棟 本家四間八間三十武坪」と付記されている（図 9)。原図に室 名は書き込まれていないが、「朱引サシオロシ」として朱色で区切ら れた部分（図 10 にて灰色の網かけで示す）が下屋に該当すると察せ られる。門構えと板塀も確認できる。この図面を営繕時の「横山権 少主典役宅」図面（図 11）と比較対照すると、両者とも母屋部分の 規模が 4 間 8 間となり、それを補完するように『諸調』にも後者を 指して「梁間四間桁間八間」と記されており、両者は同一物件とみ なしうる。よって明治 3 年建立の横山権少主典役宅が、風雪で大破 した龍澤寺に払下げられたと判断する。

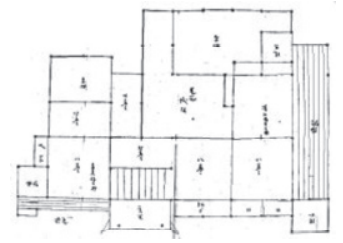

図 7 横山権少主典役宅（『諸調』）

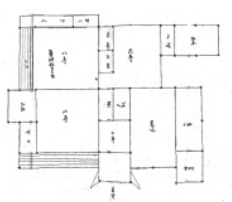

図 8 策瀬権少主典役宅（『諸調』） (『開拓使公文録』)

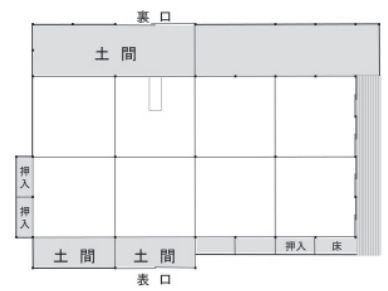

図 10 払下げ時平面、筆者図面化

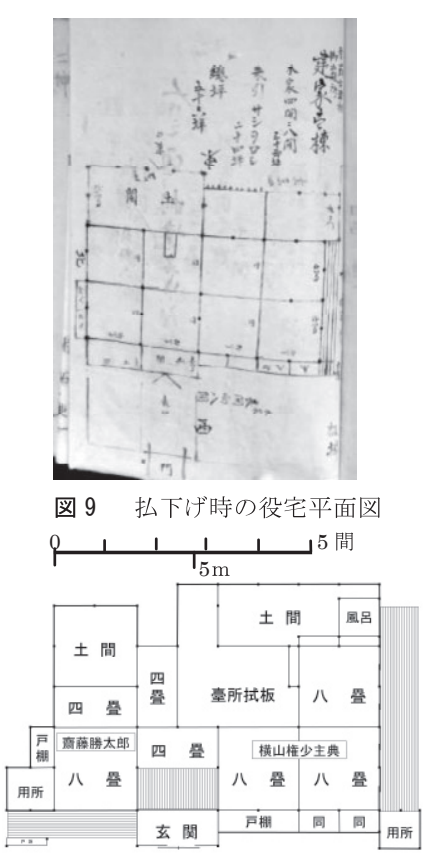

図 11 営繕時平面、筆者図面化

\section{2. 役宅営繬と建設場所の考察}

次に役宅営繥時期の考察を行う。『諸調』中「厚田役宅営繥入費凡 見積書ノ件」「新規役宅諸入費凡見積ノ件」に建設に必要な材料や 人工などの内訳と先述した平面図が添付されており、権少主典らが 赴任した同年 1870 (明治 3) 年 3 月に役宅見積が記されている。

これを裏付けるものとして、同じく『諸調』文中の「厚田郡諸調 ノ件」1870（明治 3）年 8 月に開拓使の財産目録として役宅に関す る記述が次の通り残されており、計画通り役宅は建てられたものと
判断する。

一 役邸 梁間四間 桁間八間 一棟 右横山齋藤同住

一 同 梁間四間 桁間四間半 一棟 右䈃瀬同住

役宅の建設場所については、明治 4（1871）年末から翌年にかけ て描かれた『圖面』、『調図』（図 1、2）のどちらも海側に運上家な どの交易施設、山側奥手に「出張所」、役宅」等役場機能の文字が 確認できる（図 12、13）。先述した『諸調』中では「本陣一棟 但 開拓出張所右棟内二有設」と記され、明治 3 (1870) 年 8 月の時点 では開拓出張所は本陣に設置されていたが、明治4（1871）年 10 月 に記された『厚田往復』には「當郡出張所附雑物藏壹棟兼而御買上 相成居候所右者本陣際卜離レ有之候付出納儀事不便二付御候所今度 出張所傍二移替御営繥相成候用仕度存候」とあって、本陣と出張所 とは別の場所となり、『圖面』と一致する。正確な移転時期と理由は 定かでないが、本陣内併設の出張所が役宅併設となる。明治 3 (1870) 年 11 月に横山権少主典が職務被免で帰京しており ${ }^{33)} 、 2$ 役が居住し ていた役宅の空いた場所に出張所が移転した可能性もある。

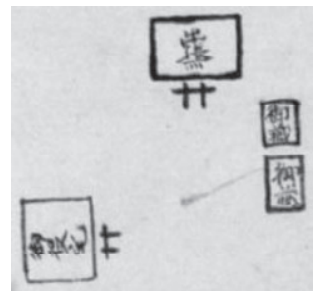

図 12 『圖面』の役宅・出張所部分

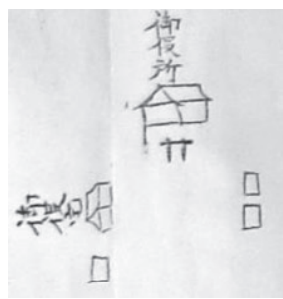

図 13『調図』の役宅・出張所部分

\section{3. 築瀬権少主典役宅の考察}

もう一方の役宅について考察を行う。横山役宅と同様に少主典ら が赴任した明治 3 （1870）年に建てられている。笵瀬は明治 5 (1872) 年に少主典から中主典へ昇格し、さらに明治 7（1874）年 1 月には 厚田出張所の石狩出張所一の統合によって北海道岩内郡一移動、後 に岩内郡長を命じられる ${ }^{34)}$ 。よって箈瀬役宅は明治 7 (1874) 年以 降は空き家となった可能性が高い。

開拓使は明治 8 (1875) 年 8 月に開拓出張所の制を廃止し、本庁 民事局派出所となる。翌明治 9 （1876）年 4 月にはこれを廃止して 分署を設置している ${ }^{35)}$ 。同期間に厚田郡官舎（役宅）の石狩分署脇 への移築が決定された記録が明治 9（1876）年 8月、『略輯旧開拓使 会計書類』の「厚田郡官舎石狩郡へ引キ建設着手ノ件」に残ってお り、平面図（図 14）も綴じられている。旧築瀬役宅を石狩分署脇 移築する運びになったと考えられるが、『諸調』中の築瀬役宅（図 17）と比べると同一物件ではないことがわかる。

そこで、諸史料を再度検討したところ、『厚田往復』中に明治 4 (1871) 年 10 月に記した「厚田郡役邸新規二棟営繥ノ件」に「當郡 詰三人居在候処役邸壹棟外無之武棟不足二而御差支相候処明中年春 雪消才第速二取掛少武棟新規御営繥相成候様仕度奉存候依是別紙繪 図面御入費調書相成此段相伺候也」との一文があり、再度の役宅営 繕願いと、平面図も綴じられている（図 15）。明治 3 (1870) 年に建 てられた役宅が、何らかの都合で 2 棟から 1 棟に減り、再営繕願い が出された年の翌年、寸なわち明治 5 (1872) 年春に新役宅が建て られて 4 年後の移築となったと考えられる。

移築時の平面図（図 16）と再営繥時の平面図（図 18）を比較する 
と、前者は連続住宅の形式をとり、がほぼ倍の規模になっている。 つまり、新役宅の建設後、もしくは同時期に、下屋部分（戸棚、流 シ、物置、湯殿）を除去して同椂の平面をもつ新棟を増築したとい うことである。かくして「新規 2 棟営縉」が叶い、厚田詰 3 名の使 員のための役宅が揃う。築瀬役宅は一旦消滅した後、再営絟され、 さらに増築を経て石狩分署脇へ移築されたことが確認できた。

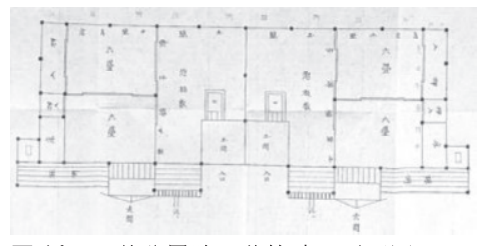

図 14 石狩分署脇へ移築時の平面図 (『略輯旧開拓使会計書類』)

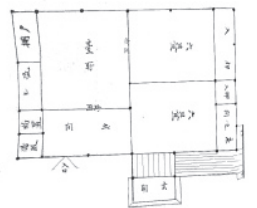

図 15 再営繥時役宅平面図 (『厚田往復』)

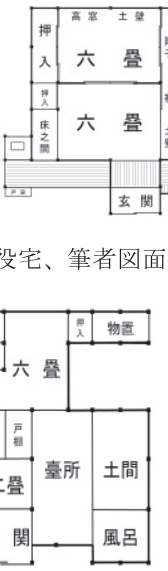

図 17 明治 3 年䇥瀬役宅設計図 筆者図面化

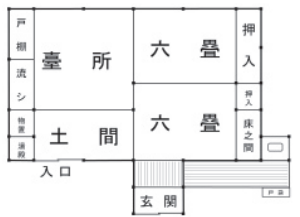

図 18 明治 4 年役宅設計図 筆者図面化
なお、『圖面』には、山側奥に出張所と役宅の 2 棟が描かれている ので、前項の考察に上記の検討を加え、同史料は、新筑瀬邸の建築 がなった明治 5 （1872）年の早い時期に制作されたと判断する。

\section{7. 考察}

\section{7-1. 厚田場所の運上屋 · 役宅の変遷}

運上家及び役宅建築の変遷をまとめると、以下の通りである（図 19)。厚田場所における運上家の建築年代は不明であるが、幕末から 明治初期にかけて、場所請負人から開拓使に移管され、その後、再 度請負人に経営委託される。下余市、積丹場所との比較でその基本 スキームを考察することは可能であるが、復元には当地の発掘調査 が必要となる。本陣、旅籠屋となった経緯をみると、宿泊所として 機能していたと思われるが、本来の出稼ぎ漁民の宿舎が古潭側の番 屋等に移り、海浜の浸食もあって早い段階で棄却されることになる。 幕末には運上家の隣にあった役宅（公役詰所）も明治初めには姿を 消寸。開拓使設置直後は運上家（本陣）が札幌から派遣された役人 の詰所となり、出張所の運上家内に置かれたが、山手裹に造られた 役宅の竣工後、しばらくして出張所や蔵も古潭側に集約される。か くして、明治初めになってヨショロコツ(本陣、蔵)、コタンベッ裏 (出張所・役宅)、コタンベツ（アイヌ居留地、和人漁民居留地）と いう土地利用区分ができるが、出張所の廃止に伴って公的機能は消 滅し、施設・官舎は払下げとなる。驛逢扱所となっていた旧運上家
の建築も、駅逓の厚田移転とともに閉鎖され、じき取り壊される。 明治初年の役宅は、開拓使建築のもつとも早い例であり、その地 方での展開として大きな意味をもつ。営繒、再営繕、払下げ、移築 というプロセスは、その建築形式以上に、施設経営の一断面を表し その後は、開拓使予算の大幅見直しとともに、役宅を建てずに民家 の借上げが行われた。

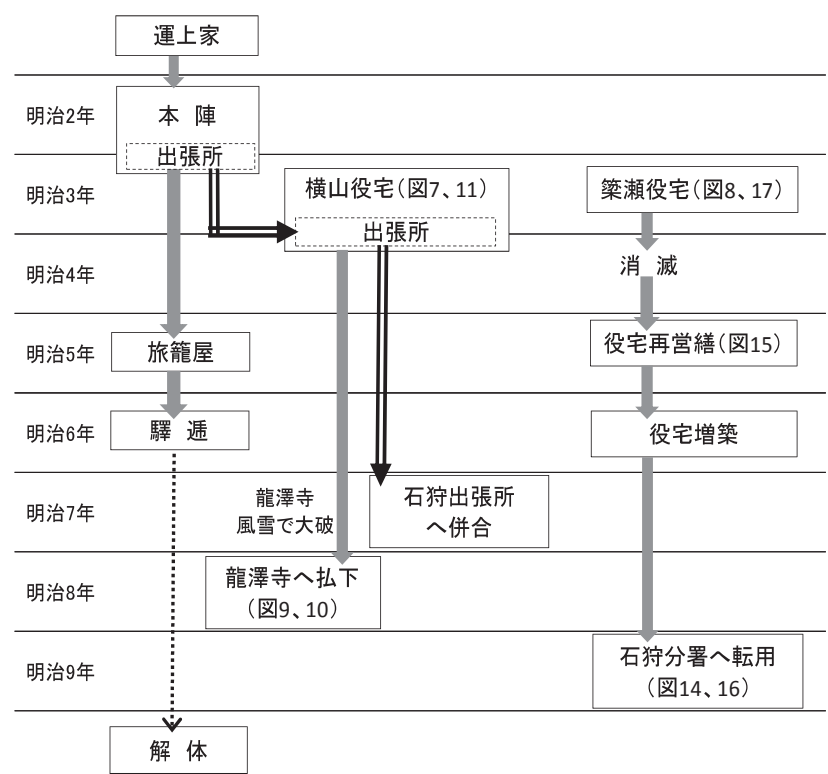

図 19 運上家と役宅の変遷

\section{7-2. 役宅建築の特徵}

役宅図面は開拓使設置直後の営繕になる明治 3（1870）年、再営 繕時の明治 4 (1871) 年、払下げ時の明治 9 (1876) 年の 3 タイプが ある。遠藤明久は、明治 2 (1869) 年の時点で札幌本府の官舎建築 について既に使員の官位に応じた規模の分類化の指針が出ている点 に着目し、『明治二己年諸留従七月至九月』を引いて次官から士分役 邸まで内訳を記している。少主典役邸については「一玄関二畳 一

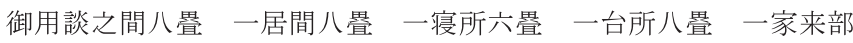
屋四畳」36）とあり、これを箈瀬権少主典の図面（図 17）に合わせ ると、家来部屋以外はす心゙て一致していることがわかり、初期の役 宅建築の基準を踏襲していることが確認できた。

明治 3 年時の役宅平面を見る限り、式台立関と座敷、台所、土間 と平面的には下級武士の住宅を踏襲している。母屋は単純な矩形平 面となし、それに下屋、雪隠（用所）、湯殿（風呂）が取り付く。構 法的には簡素化を図り、短期間での施工を可能となし、現地での必 要性に応じた増改築を容易とした点に特徵がある。南面ならびに東 西面には一部縁が設けられ、雨戸で開閉する。冬期には海からの暴 風雪を受けるオショロコツ（押琴）の交易場から離れ、コタンベツ （古潭）側の山の裏手に隠れた広い地所を構えたのは、漁民とは異 なって直接海浜に面して執務する必要がないためであろう。

この地における幕末の士分のための住宅については、『道中記』の 中に運上家と並んで公役詰所が描かれている(図 5 の右)。海防のた め西蝦夷に派遣された庄内藩は浜益を拠点としたが、当地にも詰所 を設けており、この図がそれにあたる。切妻平入りで、玄関が設け 
られたかたちは、遠藤の論文に載せられた、木造切妻で石置屋根と なった札幌の役邸（和風官舎）の写真と同一である（図 20）。運上 屋引継ぎ時の細目にはこの詰所は記載されておらず、庄内藩の引き 上げに伴って早い段階で棄却されたと思われる。

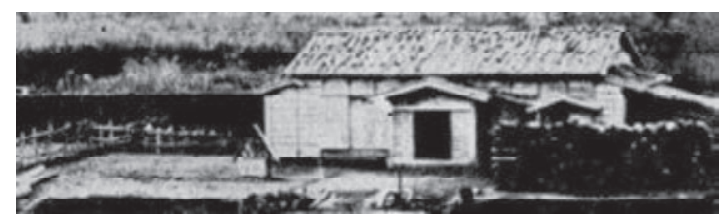

図 20 札幌の開拓使役邸、明治 3 年建設、撮影年不詳

\section{7-3. 標準化}

役宅の建設は、地元もしくは他地域からの業者が請け負った。諸 史料には大工源八なるものが牢屋の建設を請け負った旨の文書はあ るが (『厚田往復』明治 4 年)、役宅については棟梁の名を見つける ことはできない。

役宅平面を同時期の札幌の和風官舎と比較すると、母屋と下屋の 構成から見て同一系統とみなしうる住宅があるが、役宅の図面と見 積が厚田出張所から札幌の本庁に送付されているところをみると、 雛形に相当するものがあり、それを踏まえて現地の棟梁が設計施工 したと考えるのが妥当である。明治 5 年の役宅は、建築後まもなく して同一規格の住宅をその横に増築するかたちで長屋化が図られて いるが、札幌でも同時期に長屋形式での和風官舎（雨龍通長屋）が 建てられており、面積（12 坪）がほぼ共通している。このように標 準化は開拓使にとって大きな課題であったのである。

\section{8.おわりに}

本論文では現存する史料と図面をもとに、厚田場所における施設 計画が藩政期から開拓使期に移行するに際してどのような変遷を辿 ったか、運上家と役宅を中心として考察を行った。運上家の概要を 明らかにするとともに、これまで未解明であった最も早い時期の役 宅建築の形式を明らかにすることができた。施設経営に際しては既 存の建築物の転用を最大限はかり、払下げ、移築などによって再利 用がなされている。厳しい気候ゆえ、本州の諸施設とは異なった配 置計画・平面計画を伴った。開拓使の財政事情から、早い段階で出 張所・役宅（官舎）は姿を消し、以後、厚田の地は民の施設で運用 されることになる。北海道の都市形成や歴史建築の変換期を知る上 で以上の知見は重要である。

\section{注}

1）外崎由香、松下瑛美、三宅理一『江戸後期一明治初期における厚田場所の 土地利用と施設立地に関する考察その 1 』日本建築学会計画系論文集 (78) , 2013, pp. 1293-1299

2）厚田場所は現在の石狩市厚田区押琴 (ヨショロコッ) と古潭 (コタンベッ) に位置する。

3）運上家の表記は運上屋とする文書もあるが厚田場所や下余市場所に関す る藩政期・明治初年の古文書は前者の例が多くここでは前者をもって統一。

4）開拓使設置に伴って建てられた官員のための住居。開拓使文書を眺めると、 「官舎」という用語が用いられるようになるのは明治 5-6 年以降である。

5）遠藤明久『開拓使営纉事業の研究』私家版、1961。北海道大学附属北方資 料館所蔵。

6）越野武『北海道における初期洋風建築の研究』三洋印刷，1993。

7）明治 $2 \sim 3$ 年当時の人別帳、仕入、役宅見積など厚田詰の横山権少主典と
梁瀨権少主典らが記した。北海道立文書館所蔵。

8）漁業権を記すために沿岸部に閒尺が記され、集落には人名と間数、奥行 が記されている。北海道開拓資料室所蔵、制作年・制作者は記載なし。

9）安政 5（1858）年建立。浄土真宗大谷派。

10）石狩市能量寺住職板尾円仁氏所蔵の『明治初年厚田郡関係図類』に綴じ られている。制作年・制作者は記載なし。

11）明治 3〜5（1870～72）の開拓使と厚田出張所のやり取りを綴じたもの。 北海道文書館所蔵。

12）明治 7 9（1874～1876）年の地方・舟車・会計・文書・建築・憲法に 関する事項が綴じられた簿書。北海道立文書館所蔵。

13）『略輯旧開拓使会計書類 第四号第二百八十四冊二分割ノ二 札幌往復 四＼cjkstart明治九年七月ヨリ』明治 9（1876）年。北海道立文書館所蔵の簿書。

14）白山友正『松前蝦夷地場所請負制度の研究上巻』北海道経济史研究所、 1961、p. 264

15）請負人に漁獲量の二割を納め、八割が出稼人のものになる。これを二八 取りと呼び、出稼人の蔵を二八藏と呼んだ。

16) 白山友正、前提書, pp. 161-162

17）北海道『北海道の開拓と建築』第一法規出版株式会社、1987 の角幸博「漁 家建築」pp.161-162 による。

18）横山権少主典に関する詳細な記述はほとんど残っていないが、『諸調』『厚 田往復』には名が残されている。

19）慶応 $2 （ 1866 ）$ 年 9 月に北海道移住の命を受け明治 $3 （ 1870 ）$ 年 2 月 13 日に開拓権少主典として厚田出張所に赴任。明治 7 (1874) 年 1 月 28 日 に岩内勤務、明治 13 （1880）年には岩内古字郡長に命じられる。

20）作者は箱館奉行所の役人薮内於菟太郎。東西蝦夷地、北蝦夷地の地図お よび各場所の見取図が記されている。北海道大学附属北方資料館所蔵。

21）アイヌ語でアツタ、現在の石狩市厚田区に場所を開設した。その後押琴 に移転するが、厚田場所の名称をそのまま使用した。

22）北海道『新北海道史 第三巻通説二』新北海道史印刷出版共同企業体, 昭和 46（1971）年。全九巻のうち、開拓使関係については第三巻にまと められている。

23）厚田村役場所蔵の書類綴中より主として明治 $11 〜 18 （ 1878 １ 885 ）$ 年の 漁業、海産物調查、区務所引渡目録などを抄録。北海道大学附属北方資 料室所蔵。同じく、明治 11～18（1878～1885）年厚田役所各種公文書抄 録した『厚田郡役所史料』は昭和 7 年に編纂。北海道文書館所蔵。

24）『諸調』の「厚田郡諸調書ノ件」では、「本陣壱軒（朱人り元運上家）」、 「厚田郡諸調書家作調」でも「本陳（ママ）」、「厚田御場所本陣并藏々役 邸建家調」でも、「本陣一棟 但開拓出張所右棟内二有設」と記されてお り、運上家が廃止され本陣と名称を改めた点と合致する。

25）安政 6 年樺太クシュンコタンに赴いた秋田藩蝦夷地御警衛目付の道中記。 多数の絵を含む。北海道大学附属北方資料館所蔵。

26）昭和 46（1971）年に重要文化財に指定され 昭和 54（1979）年に復元さ れた。余市町『重要文化財旧下ヨイチ運上屋保存修理工事報告書』㑣北 海道機関紙共同印刷所. 1980.

27）北海道大学附属北方資料館所蔵「積丹場所運上家の平面図」、年代不明。

28）『東蝦夷日誌初編』文久 $3 \sim$ 慶応 $1 （ 1863 \sim 1865)$ 、蝦夷地探索を記した全 8 編。北海道大学附属北方資料館所蔵。

29）仮に座敷奥行を $2-2.5$ 間とすればとうり幅は $1-2$ 間、縁（片側もしく は両側）は 1 間で収まり、上手側が他の運上家同様、中廊下式であった 可能性はきわめて高い。本稿のスキームでは、東側任縁を設置した。

30）入江の湾曲した地形の平地部分に対応して地籍が分割され、その間口が 『諸調』記載の運上家ならびに二八藏に対応している。本稿で示した基 本スキームでは、この地籍境界線に従って上手・下手の区分を行った。

31 『石狩國厚田郡古潭石油地』明治 22 (1889) 年、桑名知明が描いた北海 道鉱床調查報文附図のひとつで、石油採取にために作成された地図。

32）築瀬権少主典は明治 7 （1874）年に北海道岩内町へ移動しているため、 当時の有力者であった佐藤辨藏らが嘆願書を記している。

33）『浜益・厚田往復留 明治三年午七月』中の「厚田郡詰横山権少主典職 務被免帰京旅費等渡方八件」による。

34）岡崎官次郎 編『北海道人物誌第二編』北海道人物誌編纂 1893 , pp. 99-102

35）『新北海道史』pp. 208-210

36）遠藤明久、前掲書、p. 344

（2013年 4 月 9 日原稿受理， 2013年 9 月 4 日採用決定） 